\title{
PPM Teknologi Pengemasan dan Perbaikan Manajemen Mutu (Quality Control) Usaha Mikro Pangan Di Kota Jambi
}

\author{
Surhaini, Rahayu Suseno, Ulyarti, Addion Nizori dan Mursalin \\ Dosen Fakultas Teknologi Pertanian Universitas Jambi \\ Email : surhaini@unja.ac.id
}

\begin{abstract}
Abstrak: Pengabdian pada masyarakat (PPM) Jurusan Teknologi Hasil Pertanian Fakultas Teknologi Pertanian, Universitas Jambi dengan dua mitra usaha mikro kecil menengah (UMKM) yaitu Kopi ayam Ras di The Hok Kota Jambi dan kerupuk lipat di Desa Pondok Meja Muaro Jambi telah melakukan pengabdian dengan tujuan mengatasi permasalahan mitra, yaitu teknologi pengemasan yang rendah serta umur simpan yang pendek. Tim pengabdian bertindak sebagai fasilitator dan instruktur dalam pelatihan/pendampingan antara lain perbaikan penggunaan teknologi pengemasan dan peningkatan umur simpan. Selama ini UMKM kerupuk lipat Pondok Meja hanya melakukan pengemasan dengan menggunakan karet/tali plastik pada plastic kemasan sehingga memiliki umur simpan yang pendek dan pengerjaan pengemasan yang lama yang dapat memperlambat waktu produksi. Pada UMKM Kopi Ayam Ras pengemasan bubuk kopi sudah dilakukan cukup baik. Pemilihan bahan kemasan dan metode pengemasan yang sesuai menentukan kualitas dari biji atau bubuk kopi. Hasil pelatihan diketahui dapat meningkatkan pemahaman mitra dalam meningkatkan penggunaan teknologi pengemasan yang baik sehingga produk kerupuk lipat dan kopi yang diproduksi menjadi lebih tahan lama dan mengurangi waktu produksi yang sebelumnya membutuhkan waktu lebih lama.
\end{abstract}

Kata Kunci : Kopi,KerupukLipat, Kemasan, Umur Simpan

\section{PENDAHULUAN}

UMKM (Usaha Mikro Kecil Menengah) memegang peranan yang sangat besar dalam memajukan perekonomian Indonesia. Selain sebagai salah satu alternative lapangan kerja baru, UMKM juga berperan dalam mendorong laju pertumbuhan ekonomi pasca krisis moneter tahun 1997 di saat perusahaan-perusahaan besar mengalami kesulitan dalam mengembangkan usahanya. Saat ini, UMKM telah berkontribusi besar pada pendapatan daerah maupun pendapatan Negara Indonesia (Tambunan, 2012).

UMKM merupakan suatu bentuk usaha kecil masyarakat yang pendiriannya berdasarkan inisiatif seseorang. Sebagian besar masyarakat beranggapan bahwa UMKM hanya menguntungkan pihak-pihak tertentu saja. Padahal sebenarnya UMKM sangat berperan dalam mengurangi tingkat pengangguran yang ada di Indonesia. UMKM dapat menyerap banyak tenaga kerja Indonesia yang masih mengganggur. Selain itu UMKM telah berkontribusi besar pada pendapatan daerah maupun pendapatan negara Indonesia.

UMKM mendorong pengembangan inovasi dan teknologi. Usaha Mikro Pembuatan kerupuk lipat beralamat Di Jalan Tribrata RT.12, Dusun Karya Maju Desa Pondok Meja Kecamatan Mestong, Muara Jambi. Usaha ini telah berdiri semenjak tahun 2009. Pemilik usaha ini bernama Bapak Nunu Nugraha yang meneruskan usaha secara kekeluargaan.

Barang yang didagangkan berupa kerupuk lipat dengan bahan seperti: tepung tapioka, tepung terigu, bumbu (garam, merica, bawang merah, dan bawang putih), air, dan minyak goreng. Peralatan yang di gunakan adalah: kuali, serok, alat penekan, ebeg, loyang, plastik, kompor, dan tali rafia. dengan total 1 kali produksi 30-50 kg dengan kerupuk yang dihasilkan sebanyak 1000 bungkus. Dengan harga 1 bungkus kerupuk sebesarRp 3.000,00 Keuntungan yang di peroleh dalam 1 kali pemasaran sebesarRp 2.000.000,00. 


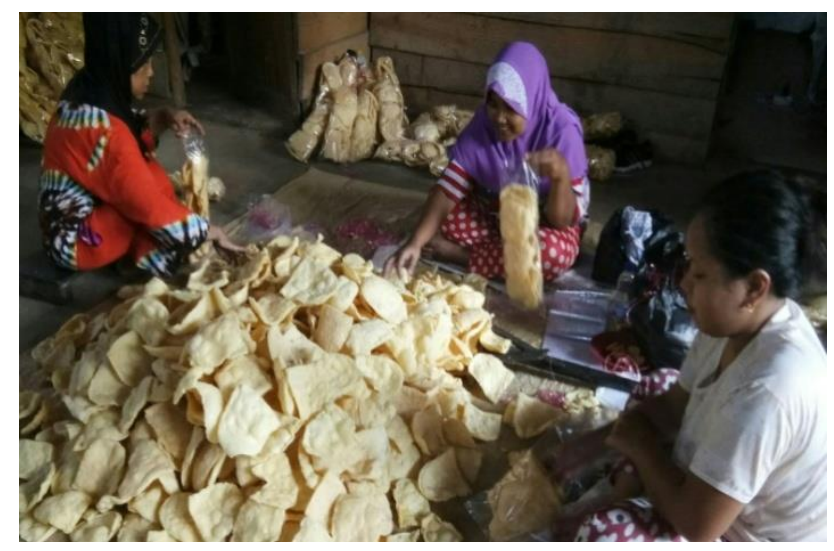

Gambar 1. Proses pengemasan kerupuk lipat

Pengemasan merupakan salah satu cara menghambat uap air lingkungan terserap oleh produk pangan kering. Kemasan juga dapat mencegah atau mengurangi kerusakan, melindungi bahan yang ada di dalamnya dari pencemaran serta gangguan fisik seperti gesekan, benturan dan getaran (Triyanto, dkk., 2013). Oleh karenanya pengemasan dapat memperpanjang umur simpan dan mempertahankan kualitas bahan lebih lama dalam hal ini umur simpan kerupuk lipat.

Usaha Mikro PD. Kopi ayam Ras (Usaha mikro 2) beralamat Jl. Raden Wijaya No. 01 Kebun Kopi Kel. The Hok -JAMBI dengan pemilik bernama Tri Sutrisno. PD. Ayam Ras bertujuan untuk memberikan inovasi varian produksi kopi yang ada di provinsi Jambi. Terletak di kota Jambi, Jl. Raden Wijaya No. 01 Kebun Kopi Kel. The Hok -JAMBI, diharapkan akan menjadi perusahaan produksi kopi yang memiliki keunggulan dari segi rasa, tekstur, maupun aroma, serta memuaskan pelanggan dari produknya.

Dari hasil wawancara usaha diversifikasi pengolahan dan pengembangan produk yang telah mulai dirintis oleh UMKM ini tidak dapat berkembang karena tidak didukung oleh penerapan ilmu pengetahuan dan teknologi (iptek) yang memadai.Tingkat pendidikan rata-rata masyarakat dan anggota kelompok tani sasaran yang hanya tamat SMP dan sebagian kecil tamat SMA, mutlak perlu pembimbingan yang terstruktur.

Permasalahan yang dihadapi oleh usaha mikro kecil dan menengah (UMKM) kerupuk lipat adalah umur simpan produk kerupuk lipat yang tidak bertahan lama karena mudah melempem yang disebabkan oleh pengemasan yang tidak baik. Waktu mengemas produk juga menjadi kendala karena pengemasan produk menggunakan karet dan tali maka membutuhkan waktu pengerjaan yang cukup lama sehingga untuk memenuhi permintaan pasar yang cukup tinggi menjadi lebih lama. Produk kerupuk lipat ini merupakan produk kering yang seharusnya memiliki umur simpan yang lama. Melalui proses pengemasan yang lebih baik diharapkan dapat memperpanjang umur simpan produk kerupuk.

Teknik dan teknologi diversifikasi produk, teknik memperpanjang umur simpan produk dan pengemasan yang baik yang akan diperkenalkan disesuaikan dengan ketersediaan peralatan yang ada pada UMKM tersebut. Teknik dan teknologi ini dimaksudkan untuk memudahkan anggota UKMK dalam pengembangan produk, tanpa harus tergantung pada teknologi dan peralatan canggih. 


\section{METODE PELAKSANAAN}

Kegiatan pengabdian pada masyarakat (PPM) dilaksanakan pada bulan MaretSeptember 2018 di UMKM kerupuk lipat Desa Pondok Meja Kecamatan Mestong Kabupaten Muara Jambi Provinsi Jambi dan Kopi Ayam Ras The Hok Kota Jambi. Alat dan bahan yang digunakan dalam kegiatan ini, antara lain: biji kopi, bubuk kopi, kerupuk lipat siap kemas, plastic pengemas dan alat pengemas berupa hand sealer. Kegiatan Iptek bagi Masyarakat (IbM) dengan mitra UMKM kerupuk lipat Desa Pondok Meja dan Kopi Ayam Ras dilakukan berdasarkan hasil identifikasi situasi dan permasalahan. Berdasarkan kesepakatan antara tim PPM Jurusan Teknologi Hasil Pertanian Fakultas Teknologi Pertanian, Universitas Jambi dan mitra Kopi Ayam Ras dan UMKM kerupuk lipat Desa Pondok Meja. Dalam upaya penyelesaian masalah, dilakukan beberapa pendekatanya itu proses pemahaman tentang peningkatan mutu produk kerupuk lipat yang telah dikemas melalui proses pengemasan yang baik serta peningkatan kualitas dan umur simpan produk kerupuk lipat.

\section{HASIL DAN KETERCAPAIAN SASARAN}

Kegiatan pengabdian pada masyarakat ini dilaksanakan pada bulan Juli, Agustus dan September 2018 di Usaha Mikro Kecil dan Menengah (UMKM) kerupuk lipat. Adapun peserta yang terlibat adalah pemilik dan penanggungjawab UMKM dan karyawan yang ada pada UMKM tersebut. Adapun tahapan awal yang dilaksanakan adalah melakukan survey dan kunjungan kelokasi tempat akan dilakukan pengabdian. Survey dilakukan pada bulan Juli 2018, selain survey awal juga dilakukan permintaan persetujuan UMKM untuk menjadi mitra pada kegiatan pengabdian ini.

Saat penandatanganan kesediaan untuk bekerjasama, dipaparkan pula kepada pemilik UMKM dan sebagian anggotanya tentang seluruh rencana kerja program dan nilai penting program terhadap pemecahan masalah yang dihadapi oleh UMKM mitra sasaran. Selain perjanjian kerjasama UMKM diminta untuk menghimpun seluruh karyawan saat akan dilakukan penyuluhan dan bimbingan teknis, serta menyiapkan tempat untuk pertemuan, penyuluhan dan bimbingan teknis selama pelaksanaan kegiatan.

Selama kegiatan berlangsung, para karyawan dan penanggungjawab di UMKM juga ikut membantu dalam menyiapkan bahan dan peralatan untuk pelatihan dan pembimbingan teknis. Selain itu para karyawan yang menjadi peserta penyuluhan turut bekerjasama dalam mensukseskan program pelatihan dan pembimbingan sehingga karyawan dapat benar-benar menerima iptek yang ditransferkan kepada mereka.

Pengemasan atau packaging merupakan upaya pembungkusan, pewadahan atau pengepakan yang memiliki peranan sangat penting untuk memperpanjang umur simpan bahan. Peningkatan permintaan pasar mengenai variasi model atau bentuk dan teknologi pengemasan yang canggih serta menarik, mendorong pelaku usaha untuk selalu berinovasi dengan teknik pengemasan yang mereka pilih. Untuk produk kopi, para penjual tentunya bisa memilih kemasan untuk membungkus kopi-kopi yang mereka jual. Pilihan ini didasari dari beberapa factor seperti lingkungan, biaya dan tampilan. Desain kemasan juga mempengaruhi pilihan konsumen pada produk kopi sehingga banyak pengusaha yang mulai memperhatikan kemasan setelah kualitas kopi dan bahan kemasan yang digunakan. 
Seperti pada Kopi Ayam Ras tidak hanya menampilkan bentuk kemasan yang menarik bagi pelanggan akan tetapi juga memiliki cita rasa dan aroma yang memiliki kwalitas tinggi. Kini perusahaan ini telah meningkatkan kwalitas dan mutu yang awalnya dikerjakan dengan cara manual kini dikerjakan dengan mesin dan kemasan yang awalnya dengan plastic biasa kini ditingkatkan dengan alumunium foil. Kemasan produk pangan, baik makanan maupun minuman mampu meningkatkan nilai jual produk yang diproduksi. Serta, memberikan keyakinan dan kenyamanan bagi produsen dan konsumen terkait status kehalalan produk pangan tersebut. Pengemasan yang baik akan menjaga tingkat kehalalan suatu produk makanan. Terkait labeling produk, produk kemasan meningkatkan nilai tambah produk makanan olahan ternak yang dikemas secara baik dan menarik. Artinya, melalui kemasan yang baik dan menarik akan meningkatkan minat konsumen terhadap produk tersebut.

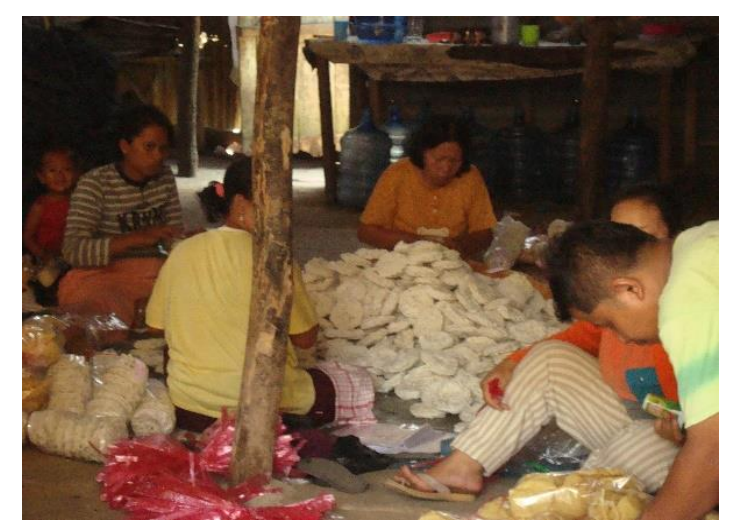

Gambar 2 Proses Penyuluhan dan pembimbingan teknik pengemasan pada UMKM kerupuk lipat saat proses pengemasan

Kegiatan penyuluhan dilakukan oleh ketua pelaksana yang dibantu dengan anggota dan mahasiswa dalam memberikan pelatihan dan bimbingan teknis mengenai teknik memperpanjang umur simpan produk dan pengemasan produk. Pada saat pelatihan disampaikan bahwa dengan menggunakan teknologi dalam mengemas produk maka dapat meningkatkan jumlah produksi pada UMKM. Proses pembimbingan berlangsung dengan cara mengumpulkan pekerja yang sedang tidak berproduksi dan dilakukan juga dengan pembimbingan langsung pada saat pekerja sedang melakukan pengemasan. Hal ini dilakukan agar proses produksi dapat terus berjalan sehingga proses penyuluhan tidak mengganggu produksi.

Setelah dilakukan penyuluhan penggunaan alat pengemas berupa sealer, para pekerja pada mulanya kesulitan untuk menggunakan alat tersebut namun lama kelamaan semakin mahir sehingga kerupuk lipat yang dijual kini sudah tidak diikat menggunakan tali plastik lagi. Produk kerupuk lipat yang dipasarkan kini menjadi tidak mudah melempem dan menjadi lebih tahan lama. 


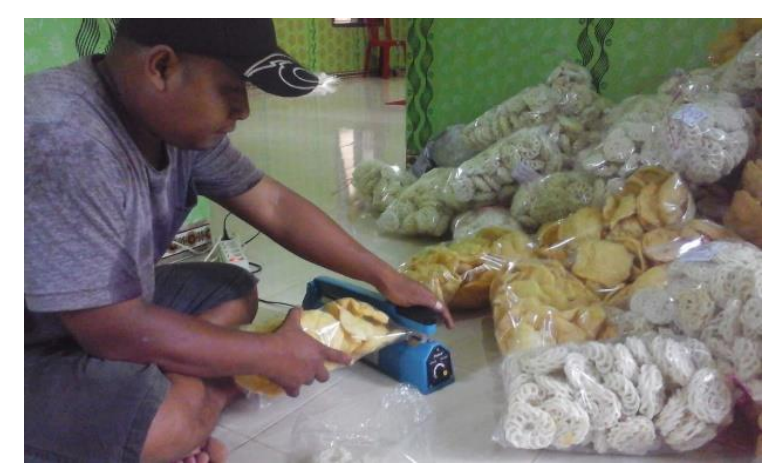

Gambar 3 Proses pengemasan kerupuk menggunakan sealer

\section{KESIMPULAN}

Kesimpulan hasil pengabdian kepada masyarakat baik dalam bentuk keberhasilan maupun hambatan yang ditemukan dalam kegiatan. Hambatan yang tertera pada bagian ini menjadi peluang bagi penulis untuk menyampaikan saran untuk keberlanjutan dan perbaikan di masa datang.

\section{DAFTAR PUSTAKA}

Tambunan, Tulus. (2012). Perekonomian Indonesia. Bogor: Gahlia Indonesia

Triyanto E., B.W.H.E. Prasetiyono, dan S. Mukodiningsih. (2013). PengaruhBahanPengemas dan Lama Simpan terhadap Kualitas Fisik dan Kimia Wafer Pakan komplit Berbasis limbah Agro industri. Animal Agriculture Journal, 2 (1), 400- 409. 